УДК 94(571.1/.5)

ББК 63.3(253)

\title{
Взаимоотношения церковных и светских властей в Сибири XVII столетия в трудах Н.Н. Оглоблина
}

\author{
И.А. Силаева \\ Научно-производственное предприятие «Сибгеокарта» \\ (Нижневартовск, Россия)

\section{Church and Secular Authorities's Relationship in Siberia of the $17^{\text {th }}$ Century in the Works of N.N. Ogloblin}

\author{
I.A. Silayeva
}

Scientific and Production Enterprise «Sibgeokarta» (Nizhnevartovsk, Russia) Известный российский историк и архивист конца
ХІХ - начала ХХ в. Н.Н. Оглоблин по ряду докумен-
тов архива Сибирского приказа в статье «Дело о само-
вольном приезде в Москву тобольского архиепископа
Симеона, в 1661 г. и третьей части фундаментально-
го труда «Обозрение столбцов и книг Сибирского при-
каза (1592-1768 гг.)» проанализировал обстоятель-
ства многочисленных конфликтов между несколькими
представителями воеводской и архиерейской вла-
стей в Азиатской России ХVII столетия. Особенно
острыми такие конфликты были при архиеписко-
пе Симеоне и управлявшими в то время Тобольским
разрядом стольником князем А.И. Буйносовым-
Ростовским и боярином князем И.А. Хилковым.

Причинами вражды Н.Н. Оглоблин считал злоупотребления воевод, прежде всего их действия, направленные на подчинение духовной власти светской.

Как выяснил ученый, архиепископ Симеон самовольно, не получив на то обязательного разрешения царя Алексея Михайловича, посетил Москву, чтобы разоблачить произвол тобольских воевод, прежде всего боярина князя И.А. Хилкова. Святитель, получив всего одну аудиенцию у государя, добился лишь удовлетворения просьб относительно материального обеспечения Софийского дома и возврата крестьян на принадлежавшие ему земли.

По данным историка, хотя тобольские архиепископы, особенно Симеон, обращались к государю с челобитными, чтобы доказать свою правоту в спорах с воеводами и ограничить своеволие разрядных администраторов, зачастую жалобы владык оставались безрезультатными из-за отсутствия у них покровителей в Москве, а также политики верховной власти, все более, главным образом с середины XVII в., пытавшейся расширить прерогативы своих наместников в Сибири.

Ключевые слова: Н.Н. Оглоблин, Сибирь, XVII в., церковь, архиепископ Тобольский Симеон, воеводы, власть, документы, духовный суд.
The famous Russian historian and archivist of the late $19^{\text {th }}-$ early $20^{\text {th }}$ centuries. N.N. Ogloblin on a number of documents from the archive of the Siberian Order in the article "The Case of the Tobolsk Archbishop Simeon's Unauthorized Arrival in Moscow, in 1661" and the third part of the fundamental "Review of the columns and books of the Siberian Order (1592-1768)" analyzed the circumstances of numerous conflicts between several representatives of the voivodship and pontifical authorities in the $17^{\text {th }}$ century Asian Russia. Such conflicts were especially acute under Archbishop Simeon and Stolnik, prince AI Buynosov-Rostovsky, who was in charge of Tobolsk discharge at that time, and Prince I. Khilkov, boyar prince and boyar. The causes of hostility N.N. Ogloblin considered the abuses of the governor, first of all their actions aimed at subordinating the secular spiritual power. As the scientist found out, Archbishop Simeon arbitrarily, without having obtained the obligatory permission of Tsar Alexei Mikhailovich, visited Moscow to expose the arbitrariness of the Tobolsk governor, first of all the boyar Prince I.A. Khilkov. The saint, having received only one audience with the sovereign, achieved only satisfaction of requests for the material support of the Sofia house and the return of the peasants to the lands belonging to him.

According to the historian, although the Tobolsk archbishops, especially Simeon, appealed to the sovereign with petitions to prove their case in disputes with the governors and limit the self-will of the bit administrators, often the lords' complaints remained fruitless due to the lack of patrons in Moscow authorities, more and more, mainly from the middle of the $17^{\text {th }}$ century, trying to expand the prerogatives of their governors in Siberia.

Key words: N.N. Ogloblin, Siberia, $17^{\text {th }}$ century, church, Archbishop Simeon of Tobolsk, vaevode, authority, documents, spiritual court.

DOI 10.14258/izvasu(2019)2-07 
Известный российский историк и архивист конца XIX - начала XX в. Н.Н. Оглоблин на основе документации Сибирского приказа раскрыл обстоятельства частых конфликтов между воеводами Тобольского разряда и архиепископами в Сибири XVII столетия.

Хотя история Азиатской России того времени часто привлекала внимание исследователей, Н.Н. Оглоблин наиболее полно и глубоко рассмотрел перипетии частых раздоров между носителями светской и духовной власти на востоке Московского государства.

Данной проблематике ученый посвятил статью «Дело о самовольном приезде в Москву тобольского архиепископа Симеона, в 1661 г.» [1] и несколько страниц 3-й части фундаментального «Обозрения столбцов и книг Сибирского приказа (1592-1768 гг.)» [2].

Разносторонне осветив судьбы административного аппарата Азиатской России, Н.Н. Оглоблин показал, что злоупотребления воевод и приказных людей в Сибири XVII в. нередко приводили к разного рода кризисным явлениям, обнаруживая несовершенство сложившейся системы управления громадным краем.

Другие исследователи, в том числе П.Н. Буцинский [3], В.А. Александров, Н.Н. Покровский [4; 5], Е.К. Ромодановская [6; 7], Е.В. Вершинин [8; 9], Д.М. Буланин [10], И.Л. Манькова [11] , Я.Г. Солодкин [12; 13], И.А. Силаева [14; 15], Н.С. Харина [16] (см. также [17]), рассматривавшие судьбы светской и церковной администрации в Сибири XVII в., обращались к данной теме попутно.

Так, П.Н. Буцинский ссылался на царские грамоты (1622 г.) воеводам, предписывающие не вступать в конфликт с духовными лицами. Однако, как отмечал видный историк, такие грамоты зачастую оставляли без внимания, в Сибири воеводы продолжали вмешиваться в сферу духовного суда, например, при архиепископе Симеоне [3, с. 289-291, 293].

Научная новизна статьи заключается в том, что труды Н.Н. Оглоблина, посвященные взаимоотношениям архиерейского дома и воеводской администрации в Сибири XVII в., впервые становятся предметом комплексного исследования. В настоящей работе проанализированы взгляды Н.Н. Оглоблина на причины конфликтов двух ветвей власти в Сибири той поры, рассмотрены суждения ученого относительно взаимоотношений между тобольскими воеводами и владыками.

При изучении данной темы наряду с традиционными методами историографического исследования использовался принцип ценностного подхода: особо выделялись те факты и явления сибирской истории, которые в представлении Н.Н. Оглоблина приобрели значение для последующих этапов вза- имоотношения духовной и светской властей в восточных уездах России.

Труды Н.Н. Оглоблина, ставшие источниками данной статьи, относятся к группе его исследований, основанных на документах архива Сибирского приказа. Из 61 опубликованной работы Н.Н. Оглоблина, посвященной прошлому Сибири, две - одна полностью, другая - частично были посвящены сложным взаимоотношениям духовных и светских властей на востоке России в XVII столетии.

Наиболее подробно Н.Н. Оглоблин осветил эту тему в статье «Дело о самовольном приезде в Москву тобольского архиепископа Симеона, в 1661 г. (Очерк из жизни XVII в.)», написанной на основании документов Сибирского приказа из Московского архива Министерства юстиции (ныне - РГАДА). Ученый выявил и ряд судных дел, отписок, челобитных, отражающих отношения между митрополитом Игнатием и властями Тобольского разряда в 1690-х гг.

Исследователь подчеркнул, что нигде, кроме Сибири, в XVII в. не было такого полнейшего «самоволия» воевод, скорее всего, по причине удаленности от Москвы. Однако назначение в Тобольск архиепископов, которые не подчинялись воеводской власти, даже, напротив, могли контролировать воевод, по мнению Н.Н. Оглоблина, умерило своеволие разрядных администраторов. Хотя не сохранился царский наказ тобольскому «первопрестольнику» Киприану, известно, что этого владыку правительство наделило правом высшего надзора «за всяким государевым делом» в Сибири [1, с. 162].

Н.Н. Оглоблин отметил, что в связи с данным наказом Киприан в 1621 г. не был радушно встречен сибирскими воеводами, уловившими смысл его назначения и служения государю.

Ученый пришел к выводу о том, что своей деятельностью в Тобольске Киприан вполне оправдал ожидания царя Михаила Федоровича и патриарха Филарета. Архиепископ постоянно вникал в нужды первопоселенцев и коренного населения края, сообщал об этих нуждах в Москву. Правительство принимало во внимание поступавшие от Киприана сведения и советовалось с ним относительно наведения порядка в Сибири.

Уже в первые месяцы своего архиепископства Киприан вызвал негодование главного сибирского воеводы боярина М.M. Годунова [1, с. 163], который даже был причастен к выступлениям служилых людей против владыки.

По мнению Н.Н. Оглоблина, при преемнике М.М. Годунова боярине князе Ю.Я. Сулешове установились благоприятные отношения между духовной и светской властями. Этот период (и при Киприане, и при сменившем его на тобольской кафедре Макарии) отмечен должным уважением служилых людей к высшей в Сибири церковной власти. 
Однако в оценке Н.Н. Оглоблина, преемники Макария Нектарий и Герасим вступили в сложные взаимоотношения с сибирскими воеводами. Энергичная деятельность новых тобольских владык, их независимое положение относительно воеводской администрации и челобитные государю относительно положения на востоке России «разжигали» борьбу светских и духовных властей [1, с. 164].

По документам известно, что московское правительство порой неприязненно относилось к Герасиму. Таким положением, - замечал Н.Н. Оглоблин, - воспользовались тобольские воеводы, превышая свои полномочия и явно вмешиваясь в «духовные дела» (вопреки царским наказам), а при архиепископе Симеоне разрядные администраторы даже пытались подчинить духовную власть светской $[1$, с. 166].

Н.Н. Оглоблин рассмотрел дела, отложившиеся в архиве Сибирского приказа, о конфликтах сибирских архиепископов и митрополитов с воеводами, которые охватывали 1655/56 - 1661/62 гг. и были посвящены раздорам между Симеоном и воеводой князем А.И. Буйносовым-Ростовским, затем его преемником князем И.А. Хилковым, а также тайному отъезду владыки в Москву.

Одно из этих дел было посвящено злоупотреблениям тобольского архиепископского дьяка И. Мильзина (племянника владыки Герасима). Сыск по этому делу (1652/53 г.) производился при новом святителе Симеоне [2, с. 179].

Обострение вражды двух властей в Сибири вызвало отъезд в 1660 г. Симеона в Москву без санкции верховной власти в надежде на помощь государя, что, по замечанию Н.Н. Оглоблина, являлось невиданным ранее поступком.

Светским администраторам Сибири стало известно об отъезде Симеона в Москву в декабре 1660 г. Они узнали и о цели поездки - подать челобитную о самоуправстве тобольского воеводы боярина И.А. Хилкова. Несмотря на уважительность причины этого смелого поступка, - писал Н.Н. Оглоблин, - внезапное оставление архиепископской кафедры являлось нарушением духовной дисциплины. (Московскому правительству было известно о конфликте между Хилковым и Симеоном. К улаживанию конфликта даже привлекалась Боярская дума, которая приняла сторону воеводы [1, с. 167]).

По указанию Н.Н. Оглоблина Симеон отправился в Москву изначально 20 августа 1660 г., выехав через свою архиепископскую вотчину в с. Ивановском, а затем водным путем до Тюмени. Однако владыка ему выбрал неподходящее судно, и пришлось вернуться, чтобы отправиться в Москву через неделю. Н.Н. Оглоблин констатировал, что Хилков не был извещен об отъезде архие- пископа и о том, кому тот поручил заведование казной и Софийским домом в свое отсутствие.

Н.Н. Оглоблин указывал на несомненно важные основания для внезапного отъезда Симеона $[1$, c. 168,170$]$. Взаимоотношения святителя с тобольскими воеводами в тот момент были наиболее обострены.

Архиепископство Симеона началось еще в пору воеводства стольника князя В.И. Хилкова, отношения у владыки с которым, на взгляд Н.Н. Оглоблина, не доходили до крайностей. Однако преемник Хилкова стольник князь А.И. Буйносов-Ростовский вступил в настоящее противостояние с духовенством еще по пути в сибирскую столицу, избив софийского сына боярского Т. Чулкова, находившегося в Тюмени в качестве архиепископского десятильника.

Деятельность А.И. Буйносова-Ростовского в Тобольске началась с приказа о запрете обращений на Софийский двор. Возмущение Симеона этим приказом обострило конфликт между воеводой и архиепископом [1, с. 171].

Служилые и жилецкие люди боялись ослушаться распоряжения А.И. Буйносова-Ростовского и не обращались к владыке по духовным делам. На Симеона подали множество ложных челобитных, к составлению которых был причастен разрядный воевода. Как следует из выявленных Н.Н. Оглоблиным документов, А.И. Буйносов-Ростовский насильно арестовывал попов и дьяконов и держал их в съезжей избе скованными [1, с. 172]. Кроме того, он, согласно челобитной Симеона, не выдавал годовой руги архиепископу и другим духовным лицам Софийского двора.

С точки зрения Н.Н. Оглоблина, А.И. БуйносовРостовский стремился выжить Симеона из владычного дома. Софийский дьяк И. Мильзин содействовал А.И. Буйносову-Ростовскому в разжигании вражды. После перехода И. Мильзина на государеву службу и смены воеводы взаимоотношения Симеона с сибирскими администраторами улучшились ненамного. Преемник А.И. БуйносоваРостовского боярин князь И.А. Хилков, констатировал Н.Н. Оглоблин, продолжал причинять Симеону неприятности [1, с. 175].

Действия Хилкова увенчались успехом, о чем свидетельствовала государева грамота, которую в 1659 г. боярин вручил Симеону. Отныне архиепископу «духовные дела» относительно служилых и жилецких людей предписывалось решать только после согласования с воеводами.

Как показал Н.Н. Оглоблин, Симеон пытался отстоять прежний порядок в отношениях духовной и светской властей. Архиепископа очень удивило распоряжение царя Алексея Михайловича - по всем духовным делам прежде всего обращаться к тоболь- 
ским воеводам и без их ведома никакие решения не принимать [1, с. 176].

Симеон старался объяснить государю, что вслед за получением этими воеводами памятей по духовным делам могут произойти волнения. Архиепископ сообщил, что к нему перестали обращаться по духовным делам, и утверждал, будто в Сибири теперь «бесчестье и наругание».

Со своей стороны, сообщал Н.Н. Оглоблин, А.И. Хилков обвинял Симеона во вмешательстве в «мирские» дела. В воеводском докладе сообщалось о том, что 28 декабря 1659 г. боярину передали заручную челобитную об оскорблении архиепископскими людьми сына боярского И. Павлуцкого с товарищами. Заручная челобитная, полученная Хилковым, по его словам, была составлена головой, детьми боярскими, сотниками и атаманами Тобольска [1, с. 178].

Учитывая это обвинение, Боярская дума и вынесла приговор, согласно которому архиепископ якобы приказывал своим людям бить государевых служилых и оскорблять их. В ответ думой было предписано избить кнутом направляемых к воеводе архиепископских людей («чтобы неповадно было»).

Вскоре, в 1660 г., по сведениям Н.Н. Оглоблина, воевода А.И. Хилков распорядился наказывать людей с Софийского двора кнутом за «воровство» архиепископа и его неугодные речи относительно И. Павлуцкого [1, с. 179].

В 1660 г. к владыке, писал Н.Н. Оглоблин, обратились крестьяне Тобольского уезда с жалобами на притеснения Хилкова, точнее, увеличение хлебных оброков. Однако Симеон не решился говорить об этом с воеводой, о чем и сообщал государю, хотя признал, что ему доводилось вмешиваться в «мирские» дела. Так, при А.И. Буйносове-Ростовском к владыке неоднократно приходили служилые люди (порой свыше 300 человек) с жалобами на притеснения воеводы и просьбами отпустить их в Москву с соответствующими челобитными (сам же воевода их не отпускал). В этих случаях Симеон велел давать служилым людям проезжие памяти, дабы предотвратить волнения. Последний такой случай, как сообщал святитель, произошел в 1659 г. Ранее, по свидетельству Симеона, с его санкции также получили проезжие грамоты челобитчики, недовольные письменным головой Н.И. Елдезиным, временно управлявшим Тюменью [1, с. 180].

Симеон в свое оправдание, по данным Н.Н. Оглоблина, привел еще одно челобитье государю - конного казака литовского списка Д. Кулагина с товарищами (30 человек), где сообщалось о притеснениях князя А.И. Буйносова-Ростовского (относительно выдачи жалованья и налогов). В челобитье констатируется и «несовет» между архиепископом и воеводой.
По мнению Н.Н. Оглоблина, Симеон знал, что в Москве он не найдет заступников, и, действительно, его «челобитья» в течение года, пока там он жил в ожидании решения государя о конфликте с Хилковым, не принесли результатов [1, с. 181].

После ряда челобитных Симеон сумел получить аудиенцию царя, однако ему были высказаны упреки в самовольном приезде, и владыке пришлось оправдываться в «особых статьях».

Н.Н. Оглоблин подчеркивал благородство Симеона, «горечь и жар» его челобитных к царю, честность, сердечность и прямоту архиепископа $[1$, с. 182].

Ученый констатировал, что хотя конфликт Симеона и Хилкова не разрешился в пользу владыки, несмотря на множество его челобитных и даже приезд в Москву, ему удалось добиться удовлетворения многих материальных нужд своей епархии. Так, крестьяне, отписанные «на государя», были возвращены Софийскому дому.

На взгляд Н.Н. Оглоблина, А.И. БуйносовРостовский и И.А. Хилков имели в Москве множество друзей, близких ко двору, почему Симеон и не смог вернуть первенство духовной власти в Сибири [1, с. 183].

Аналогичные документы за конец XVII в., привлекшие внимание Н.Н. Оглоблина, касались митрополита Игнатия, вступившего в конфликт с тобольскими воеводами ближними стольниками А.Ф. и А.А. Нарышкиными. В результате этого конфликта Игнатий отлучил воевод от церкви и даже собирался высечь публично воеводского товарища дьяка А. Протопопова. В соответствующем деле сохранилась челобитная крещенных поневоле служилых и ясачных татар, отписки Нарышкиных и Игнатия, грамоты, распросные речи, доклады [2, с. 51].

Н.Н. Оглоблин указал и на дело 1698/991699/1700 гг. о замене митрополичьих десятильников из мирских людей заказчиками от духовного чина. Оно содержало именную роспись новых духовных властей и отписки митрополита Игнатия [2, с. 52].

Н.Н. Оглоблин сослался и на судное дело конца XVII в., которое, как он писал, любопытно «для обрисовки взаимоотношений светских и духовных властей в Сибири». Там говорилось о взыскании с илимского воеводы И.А. Змеева украденных у митрополитов Павла и Игнатия денег. По указанию Н.Н. Оглоблина, названному делу предшествовал извет софийского сына боярского К. Главина [2, с. 168, 315].

Таким образом, Н.Н. Оглоблиным проанализирован обширный материал, отражающий разнообразные стороны взаимоотношений духовной и светской властей в Сибири XVII в. В исследованиях Н.Н. Оглоблина, целиком основанных на многочисленных архивных документах, раскрыты, в том чис- 
ле в комплексе материалов, отражающих борьбу святителей с произволом тобольских воевод, причины конфликтов между ними, прежде всего злоупотребления разрядных администраторов, нередко приводившие к бунтам населения, что обнаруживало несовершенство сложившейся системы управления громадным краем. По заключению Н.Н. Оглоблина, попытки духовных властей Сибири противодействовать этим воеводам преимущественно оставались безрезультатными.

Н.Н. Оглоблин показал, что, несмотря на обращения к государю тобольских архиепископов (чаще всего Симеона), стремившихся обосновать свою позицию в конфликтах с сибирскими администра- торами и ограничить своеволие разрядных управленцев, зачастую жалобы святителей оставались безрезультатными из-за отсутствия у них покровителей в Москве. Политика московского правительства, направленная на расширение полномочий своих наместников в Сибири, тоже не способствовала успехам сибирских духовных лиц в их противостоянии с воеводами.

Раскрывая истоки, ход и результаты таких конфликтов, Н.Н. Оглоблин, не учитывая в должной мере тенденции правительственной политики на восточной окраине страны, находил, что в противостоянии светских и духовных властей правы были последние, к примеру Симеон.

\section{Библиографический список}

1. Оглоблин Н. Н. Дело о самовольном приезде в Москву тобольского архиепископа Симеона, в 1661 г. (Очерк из жизни XVII в.) // Русская старина. 1893. № 10.

2. Обозрение столбцов и книг Сибирского приказа (1592-1768 гг.) / сост. Н.Н. Оглоблин. Ч. 3: Документы по сношениям местного управления с центральным. M., 1900.

3. Буцинский П.Н. Соч.: в 2 т. / под ред. С.Г. Пархимовича; сост. Ю.Л. Мандрика. Тюмень, 1999.

4. Александров В.А., Покровский Н.Н. Власть и общество: Сибирь в XVII в. Новосибирск, 1991.

5. Покровский Н.Н., Ромодановская Е.К. Предисловие // Тобольский архиерейский дом в XVII в. Новосибирск, 1994 (История Сибири. Первоисточники. Вып. 4).

6. Литературные памятники Тобольского архиерейского дома XVII века / подготовили Е.К. Ромодановская, и О.Д. Журавель. Новосибирск, 2001 (История Сибири. Первоисточники. Вып. 10).

7. Ромодановская Е.К. Сибирь и литература: XVII век. Новосибирск, 2002 (Избранные труды).

8. Вершинин Е.В. Воеводское управление в Сибири (XVII век). Екатеринбург, 1998.

9. Вершинин Е.В. Русская колонизация Северо-Западной Сибири в конце XVI-XVII вв. Екатеринбург, 2018.

10. Буланин Д.М. Симеон // Словарь книжников и книжности Древней Руси. Вып. 3, ч. 4. СПб., 2004.

11. Манькова И.Л. Сибирский архиепископ Симеон и тобольские воеводы: опыт эмпирического исследова- ния в свете теории конфликта // Уральский исторический вестник. 2012. № 3 (36).

12. Солодкин Я.Г. «Вновь среди градодержателей Сибири» (К истории воеводского управления на восточной окраине России в конце XVI -XVII вв.) // Северный регион: наука, образование, культура. 2016. № 2 (34).

13. Солодкин Я.Г. Создание Тобольского разряда: хронология и предназначение // Теория и практика государственного и муниципального управления. Вып. 8. Тюмень, 2014.

14. Силаева И.А. Документы по истории воеводского управления и служилого люда Сибири XVII столетия в оценках Н.Н. Оглоблина // Источниковедческие и историографические аспекты сибирской истории. Вып. 8. Нижневартовск, 2013.

15. Силаева И.А. По тысячам архивных документов... (Проблемы истории Сибири конца XVI - середины XVIII веков в научном наследии Н.Н. Оглоблина). Шадринск, 2015.

16. Харина Н.С. Формирование и развитие церковнокорпоративного землевладения Тобольского архиерейского дома в XVII в. // Источниковедческие и историографические аспекты сибирской истории. Вып. 8. Нижневартовск, 2013.

17. Власть в Сибири: XVI - начало XX в. / сост. М.О. Акишин, А.В. Ремнев. Новосибирск, 2005. 